\title{
Synonymy of Strains of "Lactobacillus acidophilus"' Group A2 (Johnson et al. 1980) with the Type Strain of Lactobacillus crispatus (Brygoo and Aladame 1953) Moore and Holdeman 1970
}

\author{
ELIZABETH P. CATO, ${ }^{*}$ W. E. C. MOORE, AND JOHN L. JOHNSON \\ Department of Anaerobic Microbiology, College of Agriculture and Life Sciences, Virginia Polytechnic \\ Institute and State University, Blacksburg, Virginia 24061
}

\begin{abstract}
The type strain of Lactobacillus crispatus (VPI 3199, parent strain of strain ATCC 33820) and the deoxyribonucleic acid homology reference strain of "Lactobacillus acidophilus" group A2 (strain ATCC 33197) have 100\% deoxyribonucleic acid homology. L. crispatus and strains in "L. acidophilus" group A2 also produce similar polyacrylamide gel electrophoresis patterns of soluble cellular proteins and are similar in other phenotypic characteristics. Therefore, the group A2 strains are members of the species L. crispatus (Brygoo and Aladame 1953) Moore and Holdeman 1970.
\end{abstract}

Strain VPI 3199 (= Collection of the Institut Pasteur, Paris, strain II ["Eubacterium crispatum"']) was designated the type strain of Lactobacillus crispatus (Brygoo and Aladame 1953) Moore and Holdeman 1970 in 1980 (8). Before depositing this strain in the American Type Culture Collection, we recharacterized it by using previously described methods (2). We found that growth of strain VPI $3199^{\mathrm{T}}$ was stimulated when media contained $0.02 \%$ Tween 80 (polyoxyethylene [20] sorbitan monooleate). When the reactions of the strain were determined originally, we did not test for the effect of Tween 80 on growth and did not add Tween 80 to the medium.

When duplicate tests were made in the presence and absence of $0.02 \%$ Tween 80 , the reaction results without Tween 80 were the results obtained originally and listed in the Anaerobe Laboratory Manual (2) and in early descriptions $(1,6)$. In the presence of Tween 80 , growth was stimulated greatly, and the reaction results closely approximated those obtained with strains of Lactobacillus acidophilus. The electrophoretic patterns of the soluble cellular proteins, as determined by the polyacrylamide gel electrophoresis (PAGE) method of Moore et al. (5), of strain VPI $3199^{\mathrm{T}}$ were very similar to those of strains in " $L$. acidophilus" group A2 of Johnson et al. (3) (Fig. 1).

The genetic heterogeneity of strains that have been designated $L$. acidophilus because of phenotypic similarity has been well documented $(4$, 7). In a study of 89 bacterial strains which exhibited similar biochemical reactions and previously had been identified as $L$. acidophilus,
Johnson et al. (3) found six separate deoxyribonucleic acid homology groups. These authors designated homology group $\mathrm{A} 1$ as $L$. acidophilus because it contained the type strain (ATCC 4356 [= NCIB 8690]). Strains in "L. acidophilus" group A2 had only 14 to $29 \%$ homology with strain ATCC $4356^{\mathrm{T}}$ but 60 to $78 \%$ homology with strain ATCC 33197 (= VPI 7635), which was designated the reference strain of group A2 but was not given a specific name at the time that it was described (3).

When deoxyribonucleic acid isolation and homology methods described previously (3) were used, $L$. crispatus VPI $3199^{\mathrm{T}}$ was $100 \%$ homologous with strain ATCC 33197, the reference strain of " $L$. acidophilus" group A2. Therefore, we propose that strains of " $L$. acidophilus" group A2 should be considered strains of $L$. crispatus. The type strain of $L$. crispatus, VPI 3199, has been deposited in the American Type Culture Collection as strain ATCC 33820. An amended description of this species, based on the results obtained with 14 genetically homologous strains tested in media containing $0.02 \%$ (final concentration) Tween 80 , is given below.

Lactobacillus crispatus (Brygoo and Aladame 1953) Moore and Holdeman 1970 (cris.pa'tus. L.part. adj. crispatus curled, crisped, referring to morphology observed originally in broth media).

Morphology. Cells are nonmotile, nonsporeforming, gram-positive, straight to slightly curved rods with rounded ends 0.8 to $1.6 \mu \mathrm{m}$ in diameter by 2.3 to $11.0 \mu \mathrm{m}$ long and occur singly or in short chains. After incubation for 2 days on supplemented brain heart infusion blood 


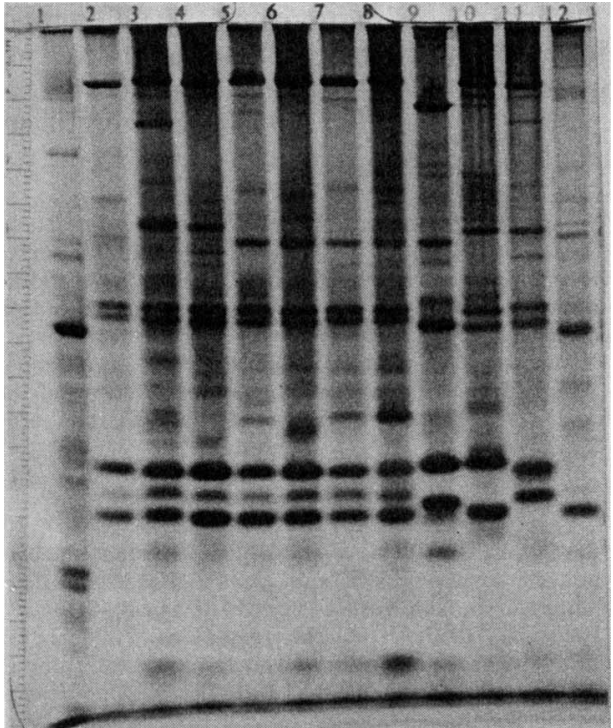

FIG. 1. PAGE patterns of strains of $L$. crispatus and $L$. acidopbilus. Lane $1, S$. faecalis, control strain, VPI U4-20. Lane 2, L. crispatus type strain, ATCC 33820 (100*). Lanes 3-8, " $L$. acidopbilus" group A2; lane 3 , ATCC 33197, human urinary tract infection, Group A2 reference strain (100); lane 4, VPI 1799 , chicken crop contents (76); lane 5, VPI 11697, Gasser SA5 (72); lane 6, VPI 1784, chicken cecum contents (71); lane 7, VPI 11761, Gasser SA11 (71); lane 8, NCTC 2949, human vagina (70). Lane 9, L. acidopbilus type strain, ATCC 4356 (26). Lane 10, "L. acidopbilus" Group A3, VPI 1754, hog small intestinal contents (31). Lane 11, "L. acidopbilus" Group A4, VPI 1294, chicken crop contents (22). Lane 12, " $L$. acidophilus" Group B1, ATCC 19992, human feces (14). Lane 13, "L. acidopbilus" Group B2, VPI 7960, human blood (18). "Homology with ATCC 33197 given in parentheses.

agar plates in anaerobe jars with a gas mixture containing $10 \% \mathrm{CO}_{2}$ and $90 \% \mathrm{H}_{2}$ (2), colonies are minute to $1.0 \mathrm{~mm}$ in diameter, entire to slightly scalloped, convex to pulvinate, translucent at the edge to opaque in the center, and grayish white to tan. Colonies have a smooth shiny surface; a granular or mosaic internal structure occasionally is observed. Although growth is best on plates incubated in an anaerobic atmosphere, all strains grow well in candle extinction jars, and 12 of the 14 strains produce slight growth on blood agar plates incubated in air.

Cultural characteristics. Growth is stimulated markedly in the presence of $0.02 \%$ Tween 80 . Strains grow equally well at 37 and $45^{\circ} \mathrm{C}$, less well at $30^{\circ} \mathrm{C}$, and poorly at $25^{\circ} \mathrm{C}$. Addition of $6.5 \% \mathrm{NaCl}$ completely inhibits growth. In broth media containing a fermentable carbohydrate, there is slight turbidity and a smooth to granular sediment. After 5 days of incubation in peptonepepticase-yeast extract-glucose-Tween 80 broth, the $\mathrm{pH}$ of a culture of strain ATCC $33820^{\mathrm{T}}$ is 3.8 .

Biochemical reactions. All strains produce acid from cellobiose, esculin, fructose, galactose, glucose, lactose, maltose, mannose, salicin, starch, and sucrose. No strain ferments arabinose, dulcitol, inositol, mannitol, melezitose, rhamnose, sorbitol, or xylose.

Esculin and starch are hydrolyzed, but hippurate is not.

An acid curd is formed in milk; neither milk, gelatin, nor meat is digested.

Nitrate is not reduced. Indole is not formed. Neither catalase, urease, lecithinase, nor lipase is detected.

Reactions that are variable among strains are listed in Table 1.

Fermentation products. The following fermentation acids, in milliequivalents per $100 \mathrm{ml}$, are detected in a 5-day-old glucose broth culture of strain ATCC 33820 ${ }^{\mathrm{T}}$ : lactic, 10.3; acetic, 0.4; and succinic, 0.4. The proportions of acids formed by all strains are similar. The lactic acid produced is a racemic mixture in which the percentage of the $\mathrm{L}(+)$ isomer ranges from 25 to $49 \%$.

Pyruvate is converted to acetate and lactate. Neither lactate nor threonine is utilized. Ammonia is not formed from arginine.

TABLE 1. Characteristics of strains of L. crispatus where strain-to-strain variation occurred

\begin{tabular}{cccc}
\hline Characteristic & $\begin{array}{c}\text { ATCC } \\
33820 \\
\text { (type) }\end{array}$ & ATCC & $\begin{array}{c}\text { Other } \\
\text { homologous } \\
\text { strains }\end{array}$ \\
\hline
\end{tabular}

\begin{tabular}{lllr}
\hline Acid from: & & & \\
$\quad$ Amygdalin & $\mathbf{w}^{a}$ & $\mathbf{w}$ & $5(12)^{b}$ \\
Erythritol & - & - & $2(12)$ \\
Glycogen & + & - & $8(12)$ \\
Melibiose & $\mathbf{w}$ & - & $9(12)$ \\
Pectin & - & - & $2(11)$ \\
Raffinose & + & $\mathrm{w}$ & $10(12)$ \\
Ribose & - & - & $1(12)$ \\
Trehalose & - & - & $1(12)$ \\
\hline
\end{tabular}

$a_{+, \mathrm{pH}}$ less than $5.4 ; \mathrm{w}, \mathrm{pH} 5.4-5.8 ;-, \mathrm{pH}$ 5.8 and above.

$b_{\text {Number of strains positive (no. strains }}$ tested). 
Neither hydrogen, $\mathrm{H}_{2} \mathrm{~S}$, nor ammonia is produced. Small amounts of gas are formed in glucose agar deep cultures by four strains. Carbon dioxide is detected in the headspace gas of fructose broth cultures (chromatographic analysis).

Susceptibility to antimicrobial agents. All strains are susceptible to chloramphenicol (12 $\mu \mathrm{g} / \mathrm{ml})$, clindamycin $(1.6 \mu \mathrm{g} / \mathrm{ml})$, and erythromycin $(3 \mu \mathrm{g} / \mathrm{ml})$, as determined by the broth disk diffusion method of Wilkins and Thiel (9). The type strain and seven other strains are susceptible to penicillin $\mathrm{G}(2 \mathrm{U} / \mathrm{ml})$ and tetracycline $(6$ $\mu \mathrm{g} / \mathrm{ml}$ ); four strains are resistant to these concentrations of penicillin $\mathbf{G}$ and tetracycline.

Cell wall composition. Norbert Weiss of the Deutsche Sammlung von Microorganismen (personal communication) has determined that the murein of the type strain (ATCC 33820) is of the lysine-aspartic acid type, that glycerol teichoic acid is present in the cell wall, and that the electrophoretic mobility of the L-lactic acid dehydrogenase is the same as that of representatives of " $L$. acidophilus" group A2 of Johnson et al.

Habitat. We do not know the source of strain ATCC $33820^{\mathrm{T}}$, but early descriptions $(1,6)$ indicate that strains of $L$. crispatus were isolated from human buccal cavities and from a patient with purulent pleurisy. Strains also have been isolated from clinically healthy vaginal tracts, from a patient with leukorrhea, from a patient with a urinary tract infection, and from the crops and ceca of chickens.

Guanine-plus-cytosine. The guanine-plus-cytosine content of the deoxyribonucleic acid of strain ATCC $33820^{\mathrm{T}}$ is $35 \mathrm{~mol} \%$. Base ratios for other strains in this species range from 35 to 38 mol\% (3).

Type strain. The type strain is ATCC 33820 (= VPI 3199, = CIPP II).
Strains of $L$. crispatus cannot be differentiated reliably from strains in the other five genetic groups of $L$. acidophilus by any phenotypic test which we have used except electrophoretic analysis of the soluble cellular proteins.

We are most grateful to Norbert Weiss for information on the cell wall structure, to Lillian V. Holdeman for critically reviewing the manuscript, to Donald E. Hash for the electrophoretic analyses, and to Luba Fabrycky and Barbara Harich for excellent technical assistance.

This work was supported by Public Health Service grant AI 15244-01A from the National Institute of Allergy and Infectious Disease and by Commonwealth of Virginia project 2022820.

\section{LITERATURE CITED}

1. Brygoo, E. R., and N. Aladame. 1953. Étude d'une espèce nouvelle anaérobie stricte du genre Eubacterium: $E$. crispatum n. sp. Ann. Inst. Pasteur Paris 84:640-641.

2. Holdeman, L. V., E. P. Cato, and W. E. C. Moore (ed.). 1977. Anaerobe laboratory manual, 4 th ed. Anaerobe Laboratory, Virginia Polytechnic Institute and State University, Blacksburg.

3. Johnson, J. L., C. F. Phelps, C. S. Cummins, J. London, and F. Gasser. 1980. Taxonomy of the Lactobacillus acidophilus group. Int. J. Syst. Bacteriol. 30:53-68.

4. Lauer, E., C. Helming, and O. Kandler. 1980. Heterogeneity of the species Lactobacillus acidophilus (Moro) Hansen and Moquot as revealed by biochemical characteristics and DNA-DNA hybridisation. Zentralbl. Bakteriol. Parsitenkd. Infektionskr. Hyg. Abt. 1 Orig. Reihe C 1:150-268.

5. Moore, W. E. C., D. E. Hash, L. V. Holdeman, and E. P. Cato. 1980. Polyacrylamide slab gel electrophoresis of soluble proteins for studies of bacterial floras. Appl. Environ. Microbiol. 39:900-907.

6. Prévot, A. R. 1957. Manuel de classification et de détérmination des bactéries anaérobies, 3rd ed. Masson and Co., Paris.

7. Sarra, P. G., M. Magri, V. Bottazzi, and F. Dellaglio. 1980 Genetic heterogeneity among Lactobacillus acidophilus strains. Antonie van Leeuwenhoek J. Microbiol. Serol. 46:169-176.

8. Skerman, V. B. D., V. McGowan, and P. H. A. Sneath (ed.). 1980. Approved lists of bacterial names. Int. J. Syst. Bacteriol. 30:225-420.

9. Wilkins, T. D., and T. Thiel. 1973. A modified broth-disk method for testing the antibiotic susceptibility of anaerobic bacteria. Antimicrob. Agents Chemother. 3:350-356. 